\title{
Price Stability and Japanese Monetary Policy
}

\author{
Robert L. Hetzel
}

For most of the time since 1995, the Japanese price level has declined. Since early 1999, short-term interest rates have mostly remained near zero. Also, starting in 2001, the excess reserves held by banks have risen dramatically. Many observers have concluded that central banks are powerless to end deflation when short-term interest rates are near zero. This paper argues that such a pessimistic conclusion is unwarranted.

Keywords: Japanese monetary policy; Bank of Japan; Deflation; Liquidity trap

JEL Classification: E5 


\section{Introduction}

Since the early 1980s, a remarkable change has occurred in the political and popular consensus about central banks. According to the new consensus, central banks should control inflation. They should do so without wage and price controls and various forms of moral suasion and government interference with private price setting. They should possess "instrument independence" to change the interest rate by whatever amount necessary to control inflation.

However, the recent deflationary experience of Japan has weakened the consensus about the extent of central bank control over deflation. Central banks can control inflation because there is no limit to how high they can raise their instrument, the interbank rate. But can they control deflation? Is there not a fundamental asymmetry that derives from the central bank's inability to push the interest rate below zero?

This debate reveals a continuing lack of intellectual consensus over how central banks determine the behavior of the price level. Opinion splits over the fundamental issues of the nature of the price level and of the monetary transmission mechanism. First, is the price level a monetary phenomenon determined by the way that the central bank controls money creation? Alternatively, is it a non-monetary phenomenon determined by a multiplicity of real factors that exercise their influence on the price level directly rather than indirectly through their effect on the money stock and real money demand? Second, does the central bank exercise its control over prices through money creation that forces portfolio rebalancing by the public? Alternatively, does it exercise its control through influence over financial intermediation?

In this paper, I argue against the view that Japanese deflation reveals an asymmetry in the ability of central banks to control inflation and deflation. ${ }^{1}$ The issue of whether central banks can control deflation when the short-term interest rate is zero is the same as the issue in the 1970s over whether central banks can control inflation. If inflation is a monetary phenomenon and portfolio rebalancing propagates the monetary policy actions of the central bank, then control over money creation endows the central bank with the power to control deflation as well as inflation.

If inflation is a monetary phenomenon, the price level varies to give the nominal money stock the real purchasing power desired by the public. Because the central bank retains control of money creation, it retains the ability to end deflation even when the short-term interest rate is zero. The transmission mechanism of monetary policy remains intact. The central bank can still force portfolio rebalancing through the money creation that comes from open market purchases of illiquid assets.

This quantity theory view (Hetzel [2004]) contrasts with the popular "liquidity" view that holds that the central bank is impotent to end deflation after it has lowered the interest rate to zero. Because the lessons of the Japanese experience depend upon what monetary policy the Bank of Japan (BOJ) has followed, I examine BOJ monetary

1. Nothing in this paper is critical of Japanese monetary policy. Real GDP grew steadily in 2002 and 2003 at a rate of almost 3 percent, while the consumer price index (CPI) remained basically stable in 2003. The unemployment rate fell. The BOJ confronted many shocks in the 1990s: the sharp fall in equity and land prices that began in 1990 and the accompanying rise in the nonperforming loans of banks, the autonomous rise in the price level due to the increase in the value-added tax in April 1997, and the collapse of the IT boom in 2000. One can argue that Japanese monetary policymakers have done well in difficult circumstances. 
policy. I also propose a quantitative strategy for stabilizing the price level that makes the monetary base depend upon nominal variables like money growth and the yen expenditure of the public.

\section{The Liquidity View}

The liquidity view interprets monetary policy in terms of financial intermediation. ${ }^{2}$ "Liquidity" refers to the availability of funds (credit) rather than the services yielded by the quantity of money. The role of the central bank is to regulate the availability of funds to banks to encourage the appropriate amount and direction of financial intermediation. Monetary policy is easy if funds are readily available for lending. From this perspective, asset prices and especially speculative activity are central indicators for the central bank. Speculative activity, allowed to run unchecked, will lead to a collapse of asset prices. The difficulty of dealing with the resulting excessive debt and inventories leads to recession and deflation. Swings in asset prices and their amplifying or depressing effects on financial intermediation can overwhelm the ability of central banks to control the price level.

From this perspective, an explanation of Japanese monetary experience after 1990 begins with the collapse of the "bubble economy." In the last part of the 1980s, perhaps encouraged by an overly easy monetary policy, land and equity prices rose to unsustainable heights. The decline in asset prices with the "bursting of the bubble" limited the ability of banks to extend credit. The common practice of collateralizing loans with land led to the nonperforming-loan problem. Banks were slow to recognize this problem because of the assumption that asset prices would recover and make troubled loans viable again.

The rise in nonperforming loans entailed two consequences for bank behavior. First, banks ceased reallocating capital from unproductive to productive sectors of the economy. As a result, productivity growth fell significantly. Failure by banks to foreclose on nonperforming loans prevented the restructuring of the economy that leads to growth.

Second, banks became risk-averse. Even though the central bank provided ample liquidity, banks were unwilling to extend credit to new enterprises. Instead, they invested in safe assets, especially Japanese government bonds (JGBs). In February 1999, out of a concern for the stability of the banking system that followed the insolvencies of two large financial institutions in fall 1998, the BOJ instituted the zero interest rate policy of providing reserves at a near-zero call rate. Despite this availability of funding, bank lending continued to decline.

In March 2001, the BOJ initiated a "quantitative" easing policy. The reserves held by financial institutions with the BOJ (current account balances, or CABs) grew subsequently from $¥ 4$ trillion to $¥ 30$ trillion in fall 2003. Proponents of the liquidity view argue that the unprecedented level of CABs together with historically low money (M2+CDs) growth provides evidence that the unwillingness of banks to extend credit

2. U.S. monetary policymakers held these views in the 1920s and 1930s (Hetzel [1985]). 
has stymied the effects of easy monetary policy. The breakdown in the monetary transmission mechanism means that the $\mathrm{BOJ}$ is helpless to offset deflationary pressures through traditional means. Given the failure of banks to expand lending despite ample reserves provision, the $\mathrm{BOJ}$ must pursue unconventional measures to revive financial intermediation. An example of such a measure is the decision made in fall 2002 to buy stocks from banks. The idea is that, with fewer risky assets, banks will become willing to resume commercial lending.

\section{The Quantity Theory}

The dispute between the quantity theory and the liquidity view over whether the price level is a monetary phenomenon reflects disagreement over the direction of influence running between central bank money creation and prices. Figure 1 shows inflation and money (M2+CDs) creation. ${ }^{3}$ Inflation fell from 6 percent at the beginning of the 1980s to zero in 1987. A drop in oil prices and a rise in the exchange rate from $¥ 258$ to the U.S. dollar in 1985/I to ¥128 in 1988/I exaggerated the fall. Inflation rose near the turn of the decade. Disinflation and subsequently deflation then prevailed.

Money grew around 8 percent in the mid-1980s. It grew around 11 percent in the last part of the 1980s and then grew drastically slower starting in 1990. For most of the 1990 s, money grew around 3 percent. Both money growth and inflation declined from the 1980s to the 1990s. The exceptions to the common movements occurred after

Figure 1 Change in M2+CDs and GDP Deflator

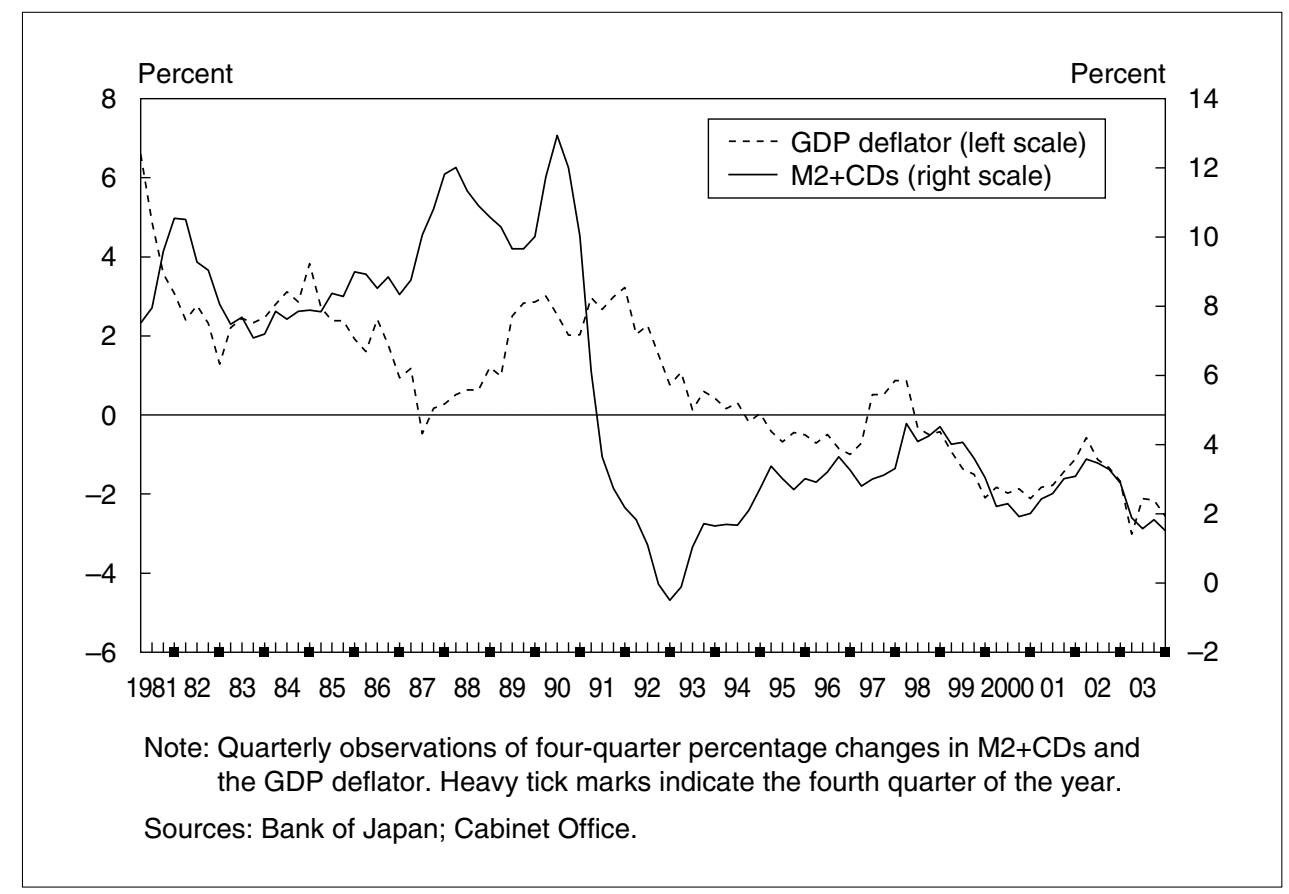

3. See Hetzel (1999) for a fuller discussion. 
1987, when the increase in inflation followed the increase in money growth with a lag and then disinflation followed the decrease in money growth again with a lag.

The liquidity view and the quantity theory provide different explanations for the common movements of the two series in Figure 1. Distinguishing between these two explanations is complicated by central bank use of an interest rate instrument. One often hears the expression, "When the central bank uses an interest rate instrument, money is demand determined." To understand the relationship between money and prices, it is necessary to clarify the ambiguities in this observation.

According to the liquidity view, as a consequence of its interest rate target, the central bank simply provides whatever money the public demands at a price level determined by non-monetary forces. The quantity theory offers a more subtle explanation. To begin, the interest rate possesses two components-a real rate and an expectation of inflation (or deflation). If the price level is a monetary phenomenon, each of these components imposes a discipline on the way that the central bank sets its interest rate peg.

The real rate of interest functions as part of the price system to reconcile individuals to an unequal intertemporal distribution of consumption. A benchmark for the real rate is the natural rate-the real rate of interest consistent with growth at the economy's potential. Money creation (destruction) allows the central bank to create a temporary divergence between the real rate and the natural rate. Such money creation forces the public into portfolio rebalancing.

The monetary acceleration at the end of the 1980s and the subsequent monetary deceleration indicate a short-term interest rate that was, respectively, too low and too high. Figure 2, which plots nominal output growth and a short-term interest rate, offers information on the thrust of monetary policy. Nominal GDP growth possesses two components: real output growth and inflation. Higher real output growth, if it leads the public to expect higher growth, implies a higher natural rate because individuals see themselves as relatively better off in the future. Higher inflation, if it leads the public to expect higher inflation, requires a higher nominal interest rate through incorporation of an inflation premium.

Figure 2 shows how after the Louvre Accord in February 1987 the BOJ maintained the call rate unchanged while nominal GDP growth rose. Maintenance of the prevailing interest rate despite a rise in the natural rate required money creation. Initially, given the credibility that the BOJ had established by the mid-1980s for price stability, money creation did not lead to higher inflation. Instead, the public rebalanced its portfolio by buying assets like stocks and land. Higher asset prices created the additional demand for the real money created by monetary expansion. Portfolio rebalancing accounts for the discrepancies observed between money growth and inflation around 1990.

The BOJ responded more promptly after the business cycle peak in February 1991 than it did after the preceding trough of November 1986. Nevertheless, the faster fall in GDP growth than in the call rate shown in Figure 2 indicates that the monetary deceleration derived from maintenance of a real rate of interest higher than the natural rate. The fall in real money, in asset prices, and in the expenditure of the public reversed the events of the preceding monetary expansion. 
Figure 2 Nominal GDP Growth and the Call Market Rate

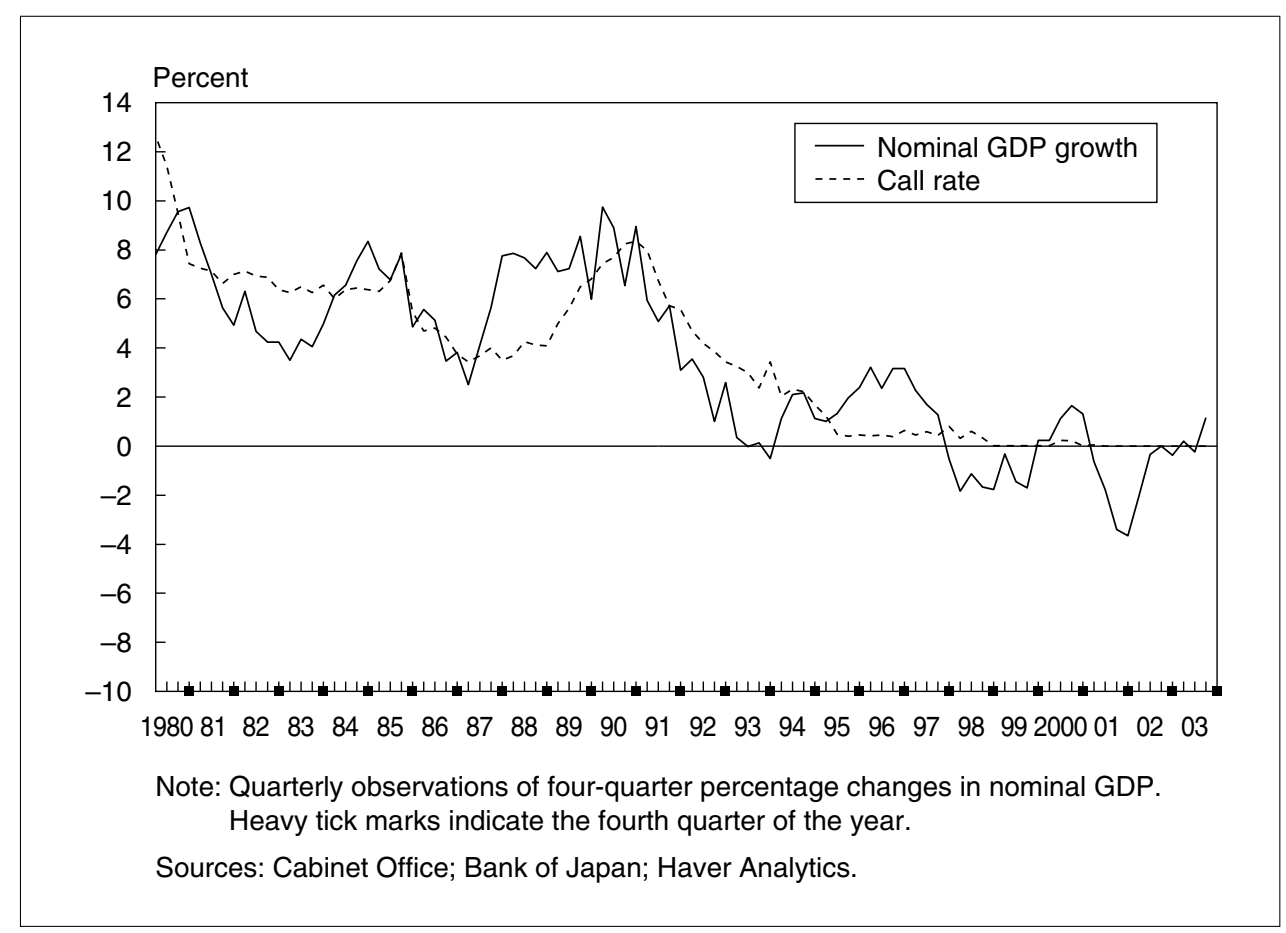

During the initial monetary acceleration, portfolio rebalancing produced higher asset prices, which led to higher expenditure. Although money demand rose in line with money supply, this situation was not a sustainable equilibrium. With a lag, increased money growth led to inflation. The subsequent monetary deceleration reversed these events. Inertia in the funds rate relative to cyclical movements in the growth of nominal output produced changes in the money stock without prior change in the public's demand for real purchasing power. Ultimately, the price level had to adjust.

In contrast, when the central bank both stabilizes the public's expectation of inflation at a level equal to its inflation target and sets short-term interest rates at a level where the implicit real rate equals the natural rate, money creation and inflation move together. A third variable, expected inflation, drives both money growth and inflation. With credibility, the central bank controls expected inflation. The common movement of money growth and inflation prior to 1987 and subsequent to 1993 suggests that in these periods the BOJ usually kept the real rate implicit in its target for the overnight call rate equal to the natural rate.

Challenges to the quantity theory view that the monetary policy of the central bank determines inflation concentrate on the two links between money creation and prices. The first link is central bank control over money creation through control of its acquisition of assets and, consequently, its liabilities (the monetary base). The second link is the ability of money creation to force portfolio rebalancing by the public. The theoretical possibility that the public simply absorbs additional money 
into its asset portfolio without attempting to move into less liquid assets is known as a liquidity trap.

As shown in Figure 3, there is no unusual strength in real money demand in Japan. That is, there is no evidence of a liquidity trap. ${ }^{4}$ Challenges to the quantity theory then must concentrate on the first link. That is, does the BOJ possess the ability to control money creation? The answer to that question is unequivocally "yes.” A central bank can increase bank deposits by simply buying an asset. The issue is whether the reservesmoney multiplier exceeds one. ${ }^{5}$ That is, in response to an open market purchase made independently of changes in banks' demand for excess reserves, will bank deposits and assets increase by a multiple of the increase in bank reserves?

\section{Figure 3 Growth of Real Money}

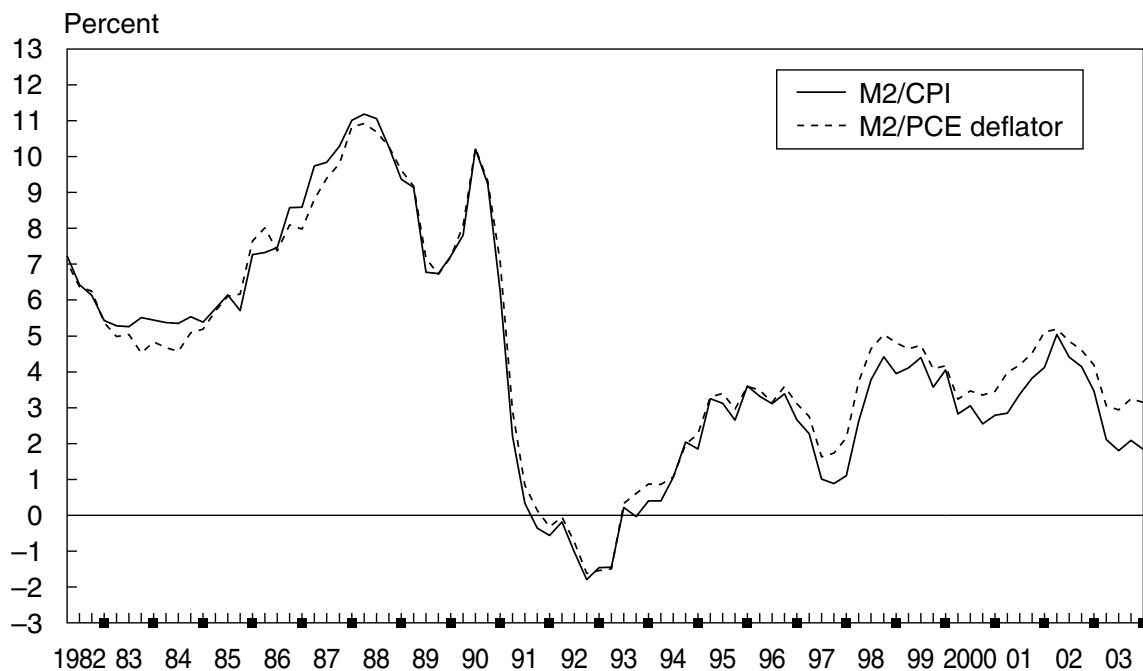

Note: Quarterly observations of four-quarter percentage changes of $\mathrm{M} 2+\mathrm{CD}$ s divided by the CPI and the PCE deflator. Heavy tick marks indicate the fourth quarter of the year.

Sources: Cabinet Office; Bank of Japan; Haver Analytics.

4. This fact leaves unresolved the issue of what assets are good substitutes for money. At a zero short-term interest rate, short-term liquid assets like Treasury bills are perfect substitutes for money. If the central bank purchases a Treasury bill, it merely exchanges one asset (money) for another (a Treasury bill) that is a perfect substitute. In this event, the public's demand for money will increase. A liquidity trap exists only if a purchase of illiquid assets by the central bank produces no attempt by the public to eliminate the increased share in its portfolio of liquid relative to illiquid assets. A liquidity trap has never been observed.

5. It is important to distinguish between a liquidity trap, which concerns portfolio rebalancing of the public, and bank adjustment to reserves changes, which concerns the behavior of the money multiplier. The first describes the behavior of individuals, and the second describes the behavior of banks. 


\section{What Is BOJ Monetary Policy?}

Resolution of the issue of whether open market purchases made independently of the demand by banks for CABs would possess the leverage on bank deposits that comes from a money multiplier greater than one will require a change in BOJ policy procedures. The high level of $\mathrm{CABs}$ held by financial institutions at the $\mathrm{BOJ}$ is striking. However, the failure of a high level of CABs to stimulate money (M2+CDs) growth does not indicate a failure of the monetary transmission mechanism caused by problems with bank solvency. Instead, it is a consequence of policy procedures that make the monetary base depend upon the demand for excess reserves by banks rather than upon the behavior of a nominal variable like money, nominal output, or the price level.

\section{A. Current Operating Procedures}

BOJ operating procedures do not in themselves offer information capable of assessing whether the increase in CABs occurred independently of an increased demand by banks. Since fall 1997, the BOJ has followed a "dual operation" strategy of simultaneously absorbing reserves by selling short-term bills and providing reserves through repurchase agreements with maturity often extending beyond the midpoint of the fiscal year or the fiscal year-end. The objective is to flatten the yield curve (Saito and Shiratsuka [2001, section V]). For example, on August 25, 2003, the BOJ Desk engaged in reserves provision by asking for bids on $¥ 800$ billion in bill repurchase agreements maturing on December $11,2003 .{ }^{6}$ Based on a competitive-bid criterion, the Desk accepted 27 percent of the $¥ 2.9$ trillion in offers. On the same day, it also engaged in reserves absorption by offering $¥ 1$ trillion in bill reverse repurchase agreements with a maturity of September 3, 2003. It accepted 21 percent of the $¥ 4.7$ trillion in offers.

Banks engage in the longer-term repurchase operations to arbitrage the small differences in the prices at which they buy from the market and sell to the BOJ. At a three- or four-month maturity, the price of a bill is low enough (the interest rate high enough) that the bank can purchase it in the market and resell it to the $\mathrm{BOJ}$ at a slightly higher price (lower interest rate). In its fund provision operations, the BOJ Desk can choose an interest rate low enough to attract sufficient bids to provide whatever amount of reserves it desires. At the same time, it regulates reserves absorption by controlling sales of Treasury and financing bills. These combined operations along with outright purchases of assets like JGBs allow the Desk to create the amount of base money required to meet the BOJ Policy Board's CAB target.

Unfortunately, these procedures offer no information on the issue of whether purposeful injections of reserves would entail a reserves-money multiplier effect. The policymaker needs to know whether the demand for CABs is inelastic or highly elastic at a near-zero call rate. However, the motivation of the individual banks that engage in open market operations offers no information about the nature of $\mathrm{CAB}$ demand. The individual banks that offer the bills to the BOJ Desk in the latter's three- to four-month reserves provision operations do so to arbitrage the difference in interest rates at which they buy and sell the bills.

6. See the monthly table "Bank of Japan Operations in the Money Markets" (www.boj.or.jp). 
Furthermore, the individual banks that buy the bills from the BOJ Desk in the reserves absorption operations do so in exchange for an asset that often pays only 0.001 percent interest. In this transaction, the two assets, CABs and short-term bills, are almost perfect substitutes. From such exchanges, one does not learn whether the total of $\mathrm{CABs}$ and short-term liquid assets is well defined. The BOJ cannot learn from these exchanges whether it can spur asset acquisition by banks by altering the ratio of illiquid assets to the total of liquid assets (CABs plus short-term securities) held by banks.

\section{B. The BOJ Strategy for Monetary Base Provision}

The high level of CABs prompts statements like "orthodox monetary policy has failed." Such statements assume that the BOJ's open market purchases conform to the textbook example of purchases made independently of the demand by banks for reserves. The implicit assumption is that the high level of CABs implies a reserves-money multiplier equal to one and, consequently, the need for large reserves injections to spur money growth. ${ }^{7}$ However, the procedures the BOJ Policy Board uses to determine the level of CABs do not provide the kind of "experiment" necessary to make such an assertion.

The reason is that the procedure the Policy Board uses to set its CAB target makes $\mathrm{CABs}$ demand determined. In particular, the Policy Board has raised its CAB target as necessary to maintain the short end of the yield curve flat. The "quantitative" policy adopted in March 2001 retains a fundamental continuity with the earlier policy adopted in fall $1997 .{ }^{\circ}$ Stated alternatively, the Policy Board has not made the quantity of CABs a function of a nominal variable like nominal expenditure growth, money growth, or misses in an inflation target. Only the latter supply-determined open market operations could decide the ease with which the BOJ can push banks off their demand schedule for reserves and revive their asset acquisition.

As background for a discussion of the BOJ Policy Board's strategy for increasing $\mathrm{CABs}$, it is important to understand the behavior of CAB demand by banks. Figure 4 shows the behavior of CABs. They increased steadily after September 2001, fell back for a while in 2002, rose steadily again starting around the end of 2002, and then rose moderately beginning in the middle of 2003. Figure 5, which shows loans in the call market, offers an explanation for the behavior of CABs.

Banks have two sources of reserves to meet unanticipated reserves outflows: the excess reserves they inventory and the reserves they borrow in the call market. The latter source has largely disappeared because the transaction costs exceed the interest earned on lending in this market. When the call rate dropped below 0.25 percent in November 1998, lending began to decline. It revived for a while after the call rate rose to 0.25 percent when the BOJ abandoned the zero interest rate policy in August 2000. It then fell again with the restoration of a near-zero interest rate with the quantitative easing policy adopted March 2001.

7. With M2+CDs equal to $¥ 686.4$ trillion in January 2004 , a 4 percentage point increase in the rate of growth of $\mathrm{M} 2+\mathrm{CD}$ s would require an initial annual increase in the monetary base of $¥ 27.5$ trillion—a 25 percent increase.

8. The spirit of these operating procedures is reminiscent of the free reserves procedures of the Federal Reserve in the 1950s. Meulendyke (1998, p. 36) wrote of the latter: "A relatively high level of free reserves was regarded as representing an easy policy: the excess reserves available to the banks were expected to facilitate more loans and investments." In that spirit, the BOJ wrote in its January 2004 Monthly Report of Recent Economic and Financial Developments, "[M]oney market conditions continue to be extremely easy, as the Bank of Japan provides ample liquidity." 


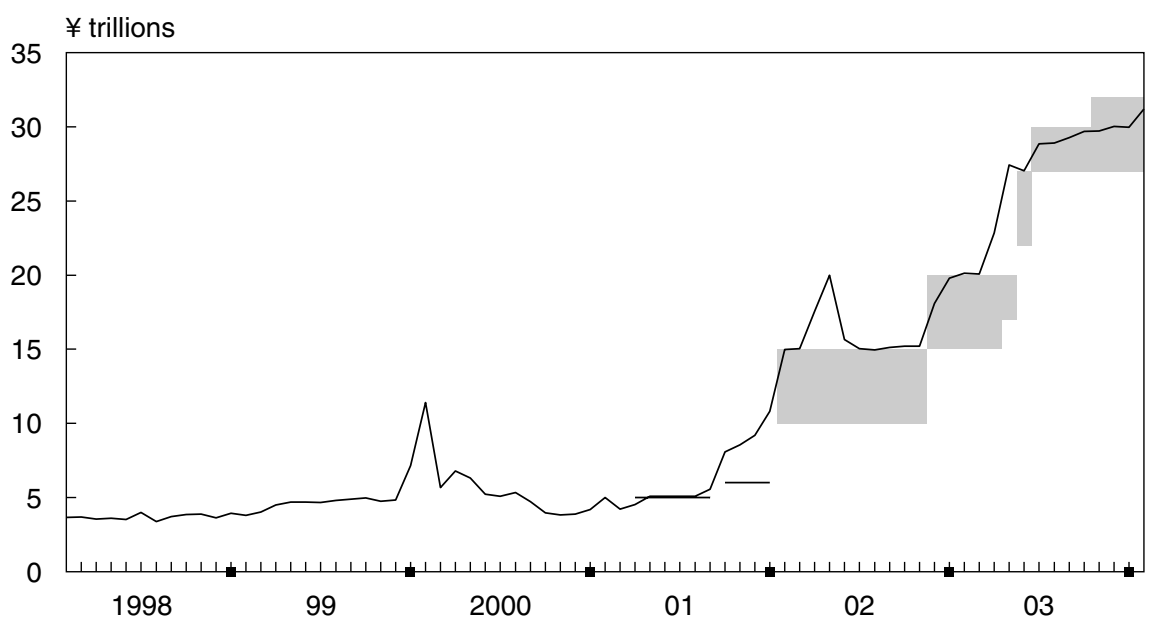

Note: $\mathrm{CABs}$ and the BOJ targets. The latter, shown below, correspond to the two steps and the shaded areas.

March 19-August 13, 2001: $\quad ¥ 5$ trillion

August $14-S e p t e m b e r 17,2001$ : $\quad$ Around $¥ 6$ trillion

September 18-December 18, 2001: Above $¥ 6$ trillion

December 19, 2001-October 29, 2002: $¥ 10-15$ trillion

October 30, 2002-March 31, 2003: $\quad ¥ 15-20$ trillion

April 1-April 29, 2003: $\quad ¥ 17-20$ trillion

April 30-May 19, 2003: $\quad ¥ 22-27$ trillion

May 20-October 9, 2003: $\quad ¥ 27-30$ trillion

October 10, 2003-January 19, 2004: $¥ 27-32$ trillion

January 20, 2004-: $\quad$ Around $¥ 30-35$ trillion

Heavy tick marks indicate the last month of the year.

Source: Bank of Japan.

The rise in the CABs of banks does not indicate an increase in bank liquidity. Banks have replaced one form of liquidity (access to the call market) with another (excess reserves). Consider the analogy of a corporation with a line of credit at a bank. The amount of liquid assets the corporation holds will increase if its line of credit ends. Similarly, banks hold additional CABs to replace the liquidity formerly offered by access to the call market. ${ }^{\text {? }}$

9. The behavior of U.S. banks in the Depression provides a precedent. In January 1936, with a Treasury bill rate of 0.1 percent, Federal Reserve member banks held US $\$ 3$ billion in excess reserves compared to US $\$ 2.7$ billion in required reserves. As expressed in the metaphor of "pushing on a string," contemporaneous observers inferred that monetary policy was impotent. That is, banks' excess reserves reflected a passive response to reserves inflows rather than increased demand. The Fed, in effect, conducted an experiment to determine the validity of this assumption. Between August 15, 1936 and May 1, 1937, the Board of Governors raised the reserve requirements on demand deposits at large money center banks from 13 to 26 percent. If banks had not desired to hold those excess reserves, the Fed's actions would have been without consequence. In the event, they produced a drastic response. By May 1937, the Treasury bill rate had risen to 0.65 percent. From 1933/IV through 1936/IV, M1 growth had averaged an annualized 15.7 percent. The level of M1 then declined from the end of 1936 to mid-1938. A strong economic recovery turned into a second recession. 
Figure 5 Total Average Uncollateralized Outstanding Loans in the Call Market

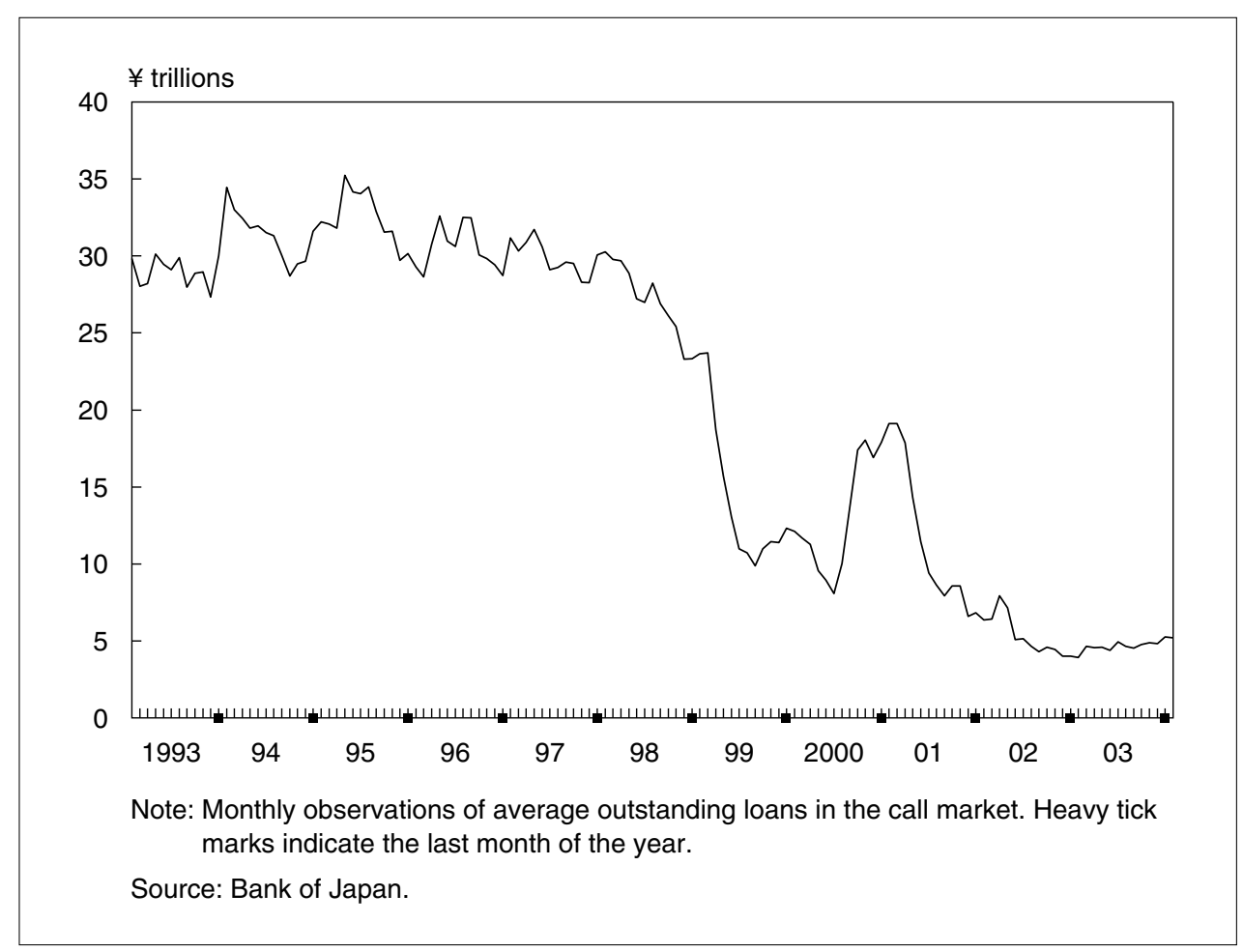

The increase in $\mathrm{CABs}$ occurred in the context of weakening bank stock prices and uncertainty over the health of some financial institutions. For Japanese banks and corporations, the end of the fiscal year on March 31 and the middle of the fiscal year on September 30 are critical days. The settling of accounts on these days has the potential to reveal a significant corporate bankruptcy. Such an event could impair the capital of the bankrupt corporation's main bank.

The resulting uncertainty created about the capital adequacy of banks creates the potential for a sudden, large reserves outflow. Banks engage in billions of dollars of transactions in an hour's time. If the participants in these transactions cease crediting the accounts of the suspect bank but continue debiting its accounts, the bank could experience enormous reserves outflows during a day. If the bank experiencing reserves outflows goes into the call market to borrow a large amount of money, it risks having a thin market turn against it. A large transaction undertaken at a rate above the going market rate would add to market rumors. Furthermore, the call market is the least liquid on the fiscal year-end and mid-year dates when banks are likely to need liquidity the most. The reason is that banks publish the figures on their balance sheets for those days. Under the Basel Capital Accords, they must hold Tier I capital against their interbank lending.

Given this uncertainty and given the low cost of holding reserves, banks maintain large amounts of reserves. When banks increase reserves demand in a period of financial stress, they leave the call market. The call market becomes even less liquid 
and less satisfactory as a source of funds to meet a large emergency demand. The demand for reserves then ratchets upward.

In the Minutes of the Monetary Policy Meeting on January 15 and 16, 2002, a member of the BOJ Policy Board explained:

[T] he Bank had been able to increase the outstanding balance of current accounts at the Bank . . . because (1) there had been concerns about the stability of the financial system since autumn 2001, (2) liquidity demand surged in preparation for funding beyond the calendar and fiscal year-end, and (3) the intermediary functions of the money market declined due to the extremely low interest rates. ${ }^{10}$

The annual summaries in the BOJ's Market Review, "Money Market Operations in FY2001" and "Money Market Operations in FY2002," chronicle the operations of the Open Market Operations Division. These reports reveal a pattern behind significant increases in CABs. In each case, there was an increase in uncertainty in financial markets followed by a slight upward tilt in the yield curve. The Policy Board then increased the target range for CABs to make the yield curve flat again at a near-zero rate for short maturities extending out several months to half a year. ${ }^{11}$

The first sustained increase in CABs began after the September 11 terrorist attacks in the United States:

This led to an increase in precautionary demand for liquidity and financial institutions increased their cash balances.... [Yields] of instruments maturing beyond the end of September firmed.... In late November [2001], precautionary demand for funds strengthened again when some money market funds experienced significant withdrawals of funds following the collapse of Enron. ${ }^{12}$

Another increase in CABs occurred toward the end of 2002:

Moving into October, uncertainty over the outlook for the financial system grew and a sharp fall in stock prices centered on the leading banks occurred. Market participants became more risk averse in the money markets. Market participants with a fund shortage took steps to procure funds, while those with fund surpluses held back from investments in the money market, choosing instead to hold their funds at the Bank.... [The] future date settlement transactions rate and the rate of term transactions such as repo and TB/FB transactions rose slightly. In response to this situation, the Bank stepped up its fund providing operations so as to enhance stability in the financial markets. ${ }^{13}$

11. The exceptions are the increases in the CAB range that occurred on October 10, 2003 and January 20, 2004. They were apparently undertaken to emphasize the BOJ's commitment to maintaining the policy of quantitative easing. The first increase resulted in no significant increase in CABs. As of early February 2004, the second appeared to have produced an increase in CABs.

12. Bank of Japan (2002b).

13. Bank of Japan (2003b). 


\section{A Proposal for a Quantitative Strategy}

A transparent monetary policy requires both an explicit target and an explicit strategy for achieving the target. A complete quantitative policy involves not only a price level target, but also a procedure for changing the instrument (the monetary base or $\mathrm{CABs}$ ) in response to misses in the target.

\section{A. The Case for an Explicit Target}

Achievement of credibility for price stability is one way of providing a nominal anchor for monetary policy. Credibility comes from having a clear, explicit target for the price level and from a demonstrated willingness by the central bank to move its instrument by whatever amount is necessary to achieve the target. Because Article 2 of the Bank of Japan Law mandates "the pursuit of price stability," the target is clear. This explicitness is important for influencing the behavior of asset prices during the process of ending deflation. Either continued expected deflation or inflation creates problems.

On the one hand, if monetary policy becomes stimulative in an environment of expected deflation, portfolio rebalancing could cause asset prices to rise to unsustainable levels. On the other hand, if the public comes to expect inflation rather than price stability, the prices of long-term bonds (JGBs) will fall significantly. A precipitate attempt by banks to unload their JGBs could produce a decline in their price sufficient to threaten some of the banks with insolvency. The foreign exchange rate of the yen might also depreciate sharply and unpredictably.

\section{B. Coping with the Zero-Bound Problem}

Current monetary policy procedures do not make CABs depend upon a nominal variable like money, nominal output, or the price level. ${ }^{14}$ Consequently, they do not provide a reliable way of providing a nominal anchor by controlling the public's expectation of the future price level.

The willingness of the BOJ to supply the amount of reserves that banks demand at a near-zero, flat short-term yield curve creates the impression that monetary policy is easy. The high level of CABs reinforces this view. In fact, the expectation of deflation can make monetary policy restrictive. Figure 6 shows the implied one-year real interest rate interest calculated as the yield on a 10-year JGB with one year to maturity minus one-year-ahead inflation forecasts from the Daiwa Institute of Research (DIR). ${ }^{15}$ Monetary policy appears easy in that the central bank makes

14. Eggertsson and Woodford (2003) argue that with a zero short-term interest rate the BOJ can pursue a more stimulative monetary policy by committing to hold short-term rates at zero for a longer period. However, their model assumes complete credibility. Steady-state inflation is automatically equal to the central bank's inflation target.

15. The fall in the price of capital goods in general and IT goods in particular causes the GDP deflator to grow at a slower rate than consumer price indices. Private capital investment is about 15 percent of GDP. The deflator for private capital investment has fallen at an annual rate of about 4 percent from 2002/III through 2003/III (Matsuoka [2003]).

Forecasts of CPI inflation imply a lower real rate of interest. Consensus Economics publishes consensus forecasts for Japan from about 20 banks and securities firms. In December 2001, 2002, and 2003, it reported forecasts for CPI inflation over the following calendar year of $-0.9,-0.7$, and -0.3 percent, respectively. The CPI (a Laspeyres index) has fallen less than the private consumption deflator (a Paasche index), which in turn has fallen less than the GDP deflator. 


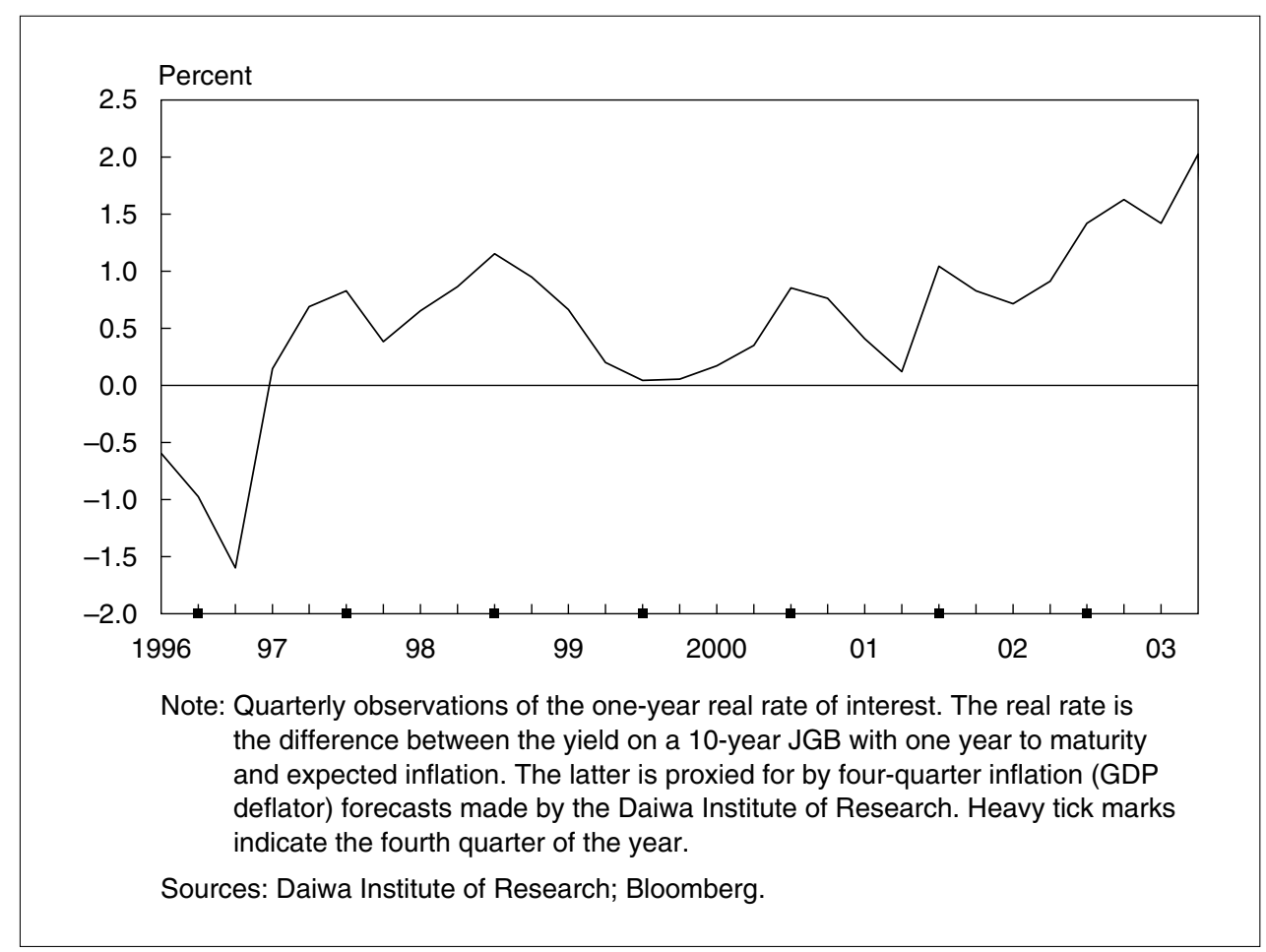

available to banks all the reserves that they demand. However, it can be contractionary if low money growth creates deflation and expected deflation creates a high real rate of interest.

The zero lower bound problem can arise when expected deflation raises the real rate of interest above zero at a nominal interest rate of zero. Expected deflation can then place a positive floor on the real rate of interest that exceeds the natural rate of interest. With an interest rate instrument, the central bank lacks a way of responding directly to negative shocks that lower the natural rate. (This problem does not occur if the magnitude of expected deflation is less than the natural rate of interest because the economy is growing rapidly.)

\section{Making the Monetary Base Depend upon a Nominal Variable}

The BOJ Policy Board could use current operating procedures to increase CABs sufficiently to stimulate growth in money and nominal GDP. The BOJ Desk would cease fund absorption operations and just do repurchase agreements to provide reserves (beyond the amount provided by outright purchases of assets like JGBs). The problem is that the asset exchanges involved in these repurchase agreements are between a completely liquid asset (bank reserves) and an extremely liquid asset (bills). Repurchase agreements that replace a bill with a bank deposit in the portfolio of the public provide little incentive for investors to move out of liquid assets into illiquid assets like stocks and real estate. 
Under the strategy proposed here, the monetary base and CABs would vary in response to the behavior of nominal variables. In the first instance, those nominal variables would be growth in money and nominal output. Ultimately, base money would vary in response to deviations of the price level from its target. The BOJ Desk would no longer engage in auctions of reserves where it accepts bids for reserves. Instead, the total quantity of reserves would depend upon a target level for the assets held by the BOJ.

The BOJ Policy Board would instruct the Desk to purchase an amount of assets that produces an amount of $\mathrm{CABs}$ to which banks must adjust. For example, on November 14, 2003, financial institutions held $¥ 30.7$ trillion in CABs. Given October 2003 over October 2002 growth of M2+CDs of only 1.5 percent, under the proposed procedures, the Policy Board would likely create a positive reserves gap by specifying a target for $\mathrm{CABs}$ in excess of the $¥ 30.7$ trillion figure. The magnitude of the excess would depend upon whether bank deposits adjust one-for-one with an increase in reserves or whether there is a reserves-money multiplier effect so that deposits adjust by some multiple.

A final change would be for the BOJ Desk to exchange all short-term, liquid assets in its portfolio for illiquid assets like 10-year JGBs. Another example of illiquid assets would be the shares of mutual funds that hold a basket of stocks that replicates the behavior of the Tokyo Stock Price Index (TOPIX). ${ }^{16}$ The Desk would conduct its open market purchases and sales in these illiquid assets. ${ }^{17}$

The reason is that at a near-zero call rate, for banks, CABs and short-term liquid debt instruments like Treasury and financing bills are perfect substitutes. Similarly, for the public, bank deposits and short-term assets are perfect substitutes. To make the demand for CABs and bank deposits well defined, the BOJ must use illiquid assets in its open market operations. ${ }^{18}$

\section{Indicators}

Because of the lags between changes in monetary base growth and changes in the price level, the central bank cannot use a simple feedback rule running from misses of

16. To avoid issues of credit allocation, the BOJ would have the shares in individual companies voted in trust by the mutual fund. If the BOJ purchased shares from a number of such funds, no individual fund would have significant voting power for an individual company.

17. The BOJ would have to change from lagged reserves accounting for calculating required reserves to contemporaneous reserves accounting. For the banking system to adjust reserves demand to a given amount of reserves supplied by the BOJ, a decline (increase) in the deposits of banks produced by asset sales (purchases) must lead to a decline (increase) in reserves demand. That can only happen with contemporaneous as opposed to lagged reserves accounting.

18. To change private behavior, the BOJ must engage in open market operations that change the proportion of liquid to illiquid assets in the public's portfolio. The alternative is to create money without an asset exchange with the public. (There is then a wealth effect as well as a portfolio rebalancing or substitution effect from money creation.) The BOJ could set a target for CABs and credit the deposit account the government holds with it by whatever amount is necessary to achieve the target. CABs would increase when the government drew down its account to purchase goods and services. The government could also use its deposits to finance transfer payments to the public, but could not use them to retire short-term debt.

Even if the BOJ exercised complete control over its credits to the government's deposit account, such a means of increasing the monetary base would raise questions about central bank independence. With the "benefits" of seigniorage so apparent, the government might be tempted to ask for legislation requiring a positive inflation target. 
the price level target to changes in the monetary base. ${ }^{19}$ The BOJ could use money (M2+CDs) and nominal output growth as indicators.

Although the money demand function exhibits considerable stability, money demand varies with a number of variables. For this reason, stable money growth is not necessarily desirable. Because real money demand depends upon interest rates (the own rate on M2 minus the market rate), wealth, and real output, the relationship between money growth and inflation holds only over long periods of time. However, inflation is a monetary phenomenon and ultimately higher money growth, initiated independently of the variables that influence money demand, must lead to higher inflation. A revival of money growth will provide the first indication that stimulative monetary policy is inducing a change in bank behavior.

The estimated money demand function in Table 1 (slightly modified from Hetzel [2003]) measures the impact on real money demand of changes in the determinants of money demand. Figure 7 shows the within-sample simulated values and actual values of real M2 growth. ${ }^{20}$ It is difficult to predict in advance what rate of growth of

\section{Table 1 Real Money Demand Regression, 1958 to 2002}

$$
\begin{aligned}
& \Delta \ln M_{t}=.21 \Delta \ln M_{t-1}+.55 \Delta \ln G D P_{t}-.036 \Delta \ln \left(R_{t}-R M_{t}\right)+.36 \Delta \ln W_{t}-.32 E_{t-1}+\hat{\mu} \\
& \text { (2.6) } \\
& C R S Q=.84 \quad S E E=2.0 \quad D W=1.8 \quad D F=39
\end{aligned}
$$

Note: The regression is in error-correction form. Observations are annual averages, except for wealth, which is a year-end observation. $M$ is $M 2+C D$ s divided by the personal consumption expenditures price deflator; $R$ is a rival interest rate paid on nonmonetary assets; $R M$ is a weighted average of the own rates of return paid on the components of M2; $W$ is real wealth. $\hat{\mu}$ is the estimated residual from a money demand regression in level form using as independent variables $G D P,(R-R M)$, and $W$. In is the natural logarithm; $\Delta$ is the firstdifference operator. $C R S Q$ is the corrected R-squared, SEE standard error of estimate, $D W$ Durbin-Watson, and $D F$ degrees of freedom. Absolute values of $t$-statistics in parentheses.

The dates for the regression are determined by the availability of data on the components of M2. Wealth data are available with a one-year lag. The Cabinet Office compiles wealth and national income and product account (SNA) data.

From 1957 through 1965, the rival rate $(R)$ is the interest rate on discounts of government securities by banks with the BOJ (boj.or.jp/en/siryo/siryo_f.htm). Thereafter, it is a modification of the series used by Sekine (1998). It is the highest interest rate from among the following instruments: three-month (gensaki) repurchase agreements, five-year loan trusts, five-year bank debentures (subscription and secondary market), and five-year postal savings. The bank debenture series is included only through 1975. Before the beginning of deregulation in the early 1970 s, it is the only available series that fluctuates. In the early 1970 s, the repurchase rate fluctuates, but less than the bank debenture rate. However, the large inflow of funds due to speculation on yen revaluation may have biased downward the repurchase rate. The own rate on money $(R M)$ is a weighted average of the own rates on the components of money (demand deposits, time deposits, savings deposits, and CDs).

19. For example, because of the volatility of expectations, the BOJ will have trouble predicting how higher nominal output growth arising from monetary stimulus will break down in the short run into higher real output growth and lessening deflation (rising inflation).

20. Because wealth becomes available with a one-year lag, the estimation period extends only through 2002. 
Figure 7 Actual and Predicted Real Money Growth

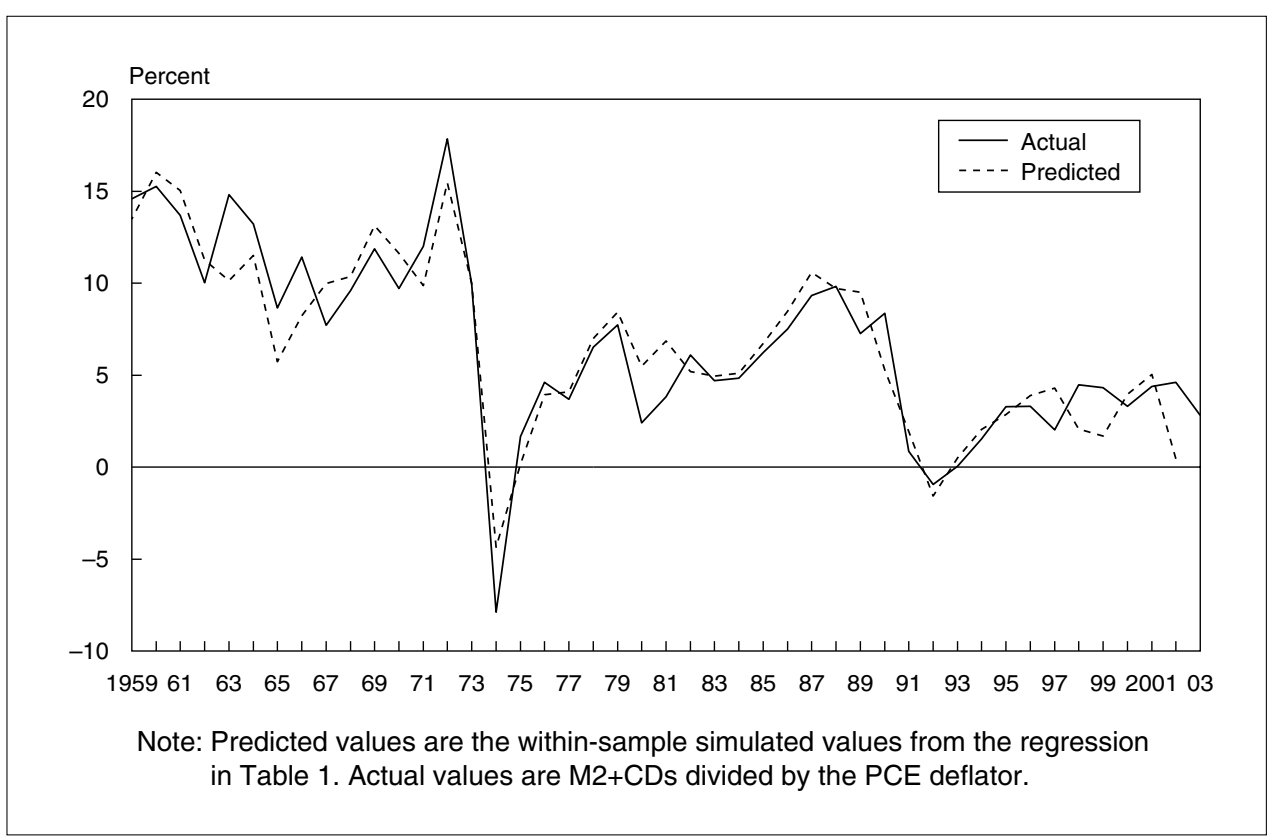

money is appropriate during economic recovery. One problem is that fluctuations in the current low value of the interest rate opportunity cost of holding M2 can cause large percentage changes in the cost of holding M2 and thus in real money demand.

In the long run, money growth consistent with price stability must accommodate the secular increase in real money demand due to factors like wealth and the increased value of individuals' time. Figure 8 shows the steady increase in the ratio of money to nominal output. Money growth consistent with price stability will equal the approximate 2 percent trend growth shown in Figure 8 plus the trend growth in real output.

To achieve price stability, the BOJ must also make nominal output grow in line with trend real output. A major issue is the trend growth rate of potential output, which depends especially upon productivity growth. Hayashi and Prescott (2002) estimate that total factor productivity (TFP) in Japan grew at an annualized rate of 0.3 percent from 1991 through 2000. Capital deepening allowed growth in productivity (output per worker) of about 1 percent. Updated figures for 2001-02 show TFP growth of 1.54 percent. Perhaps restructuring has raised TFP growth. The sum of TFP growth of 1.5 percent, productivity growth due to capital deepening of 1 percent, and a decline in the labor force of 0.5 percent yields a benchmark figure for trend real GDP growth of around 2 percent. ${ }^{21}$ 


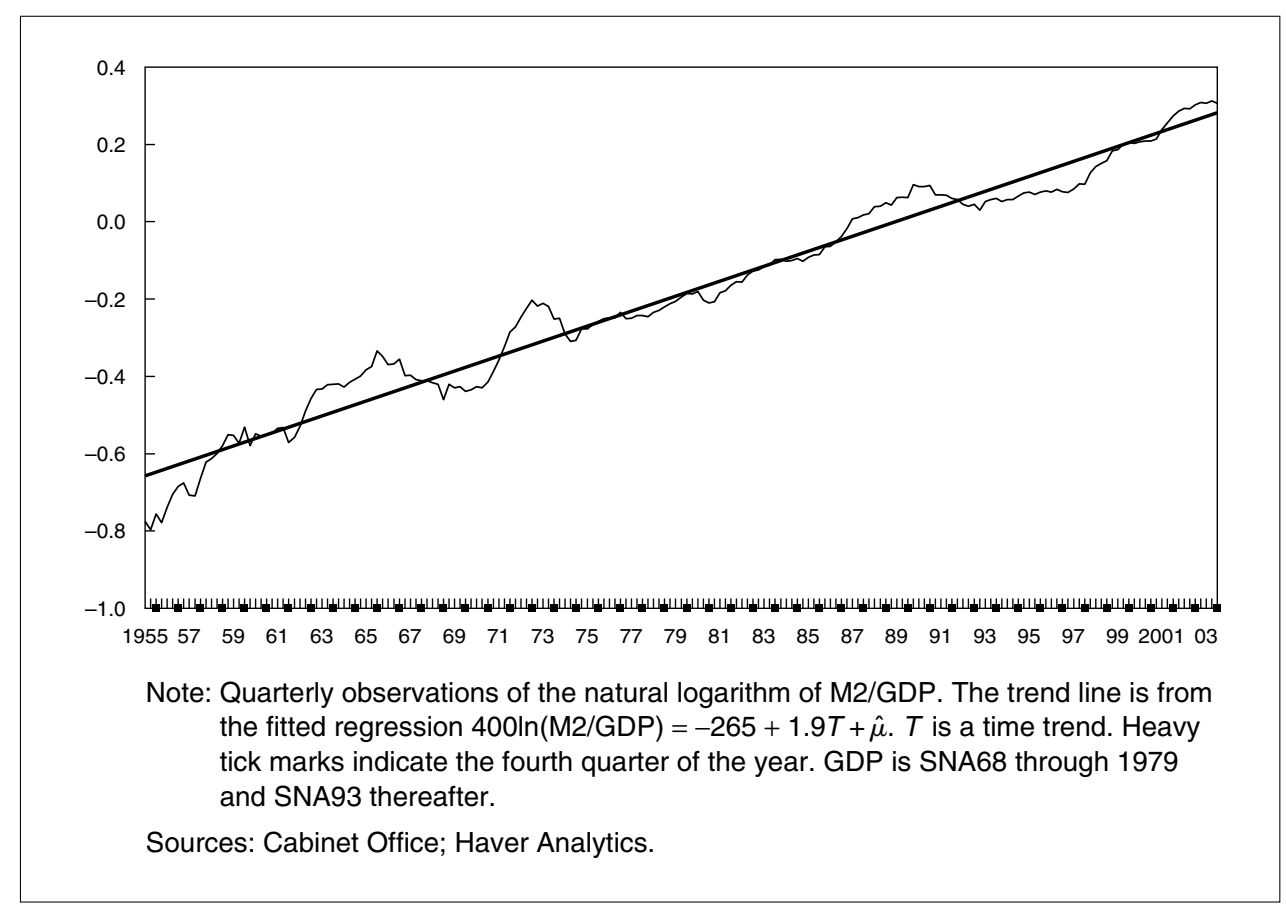

Figure 9 shows real GDP per worker hour. Since 1968 (when the hours-worked series becomes available), this measure of productivity has grown at an annualized rate of 2.6 percent, which is consistent with the figures suggested above. If trend real GDP growth is 2 percent, faster growth would diminish unemployment. In the seven quarters ending in 2003/IV, real GDP grew at an annualized rate of 3.4 percent, while the unemployment rate moved down from its peak value of 5.5 percent to 4.9 percent in December 2003. The Consensus Economics consensus forecast of real GDP growth in 2004 (made in February 2004) was 2.2 percent, with an unemployment rate of 5.1 percent-an outcome consistent with 2 percent trend growth.

A contentious issue is whether deflation has lowered productivity growth. Figure 9 shows output per worker hour rising above trend in the period of exceptionally strong growth in the latter part of the 1980s and then falling back to trend in 1997. After 1997, growth in worker productivity fell below trend (but has risen recently). As shown in Figure 10, economic forces keep real wages in line with worker productivity. (Otherwise, labor's share of income changes.) If some inflexibility in nominal wages has prevented full adjustment to deflation, corporations may have responded by raising worker productivity through substitution of capital for labor.

Such substitution raises the capital-labor ratio and validates a higher real wage but may be inefficient. Total hours worked have trended down from the beginning of 1998 through 2003 (from 2.65 to fewer than 2.55 billion hours). Since 1998, the average of scheduled hours worked has fallen 10 percent and the labor force participation 
Figure 9 Real GDP per Worker Hour

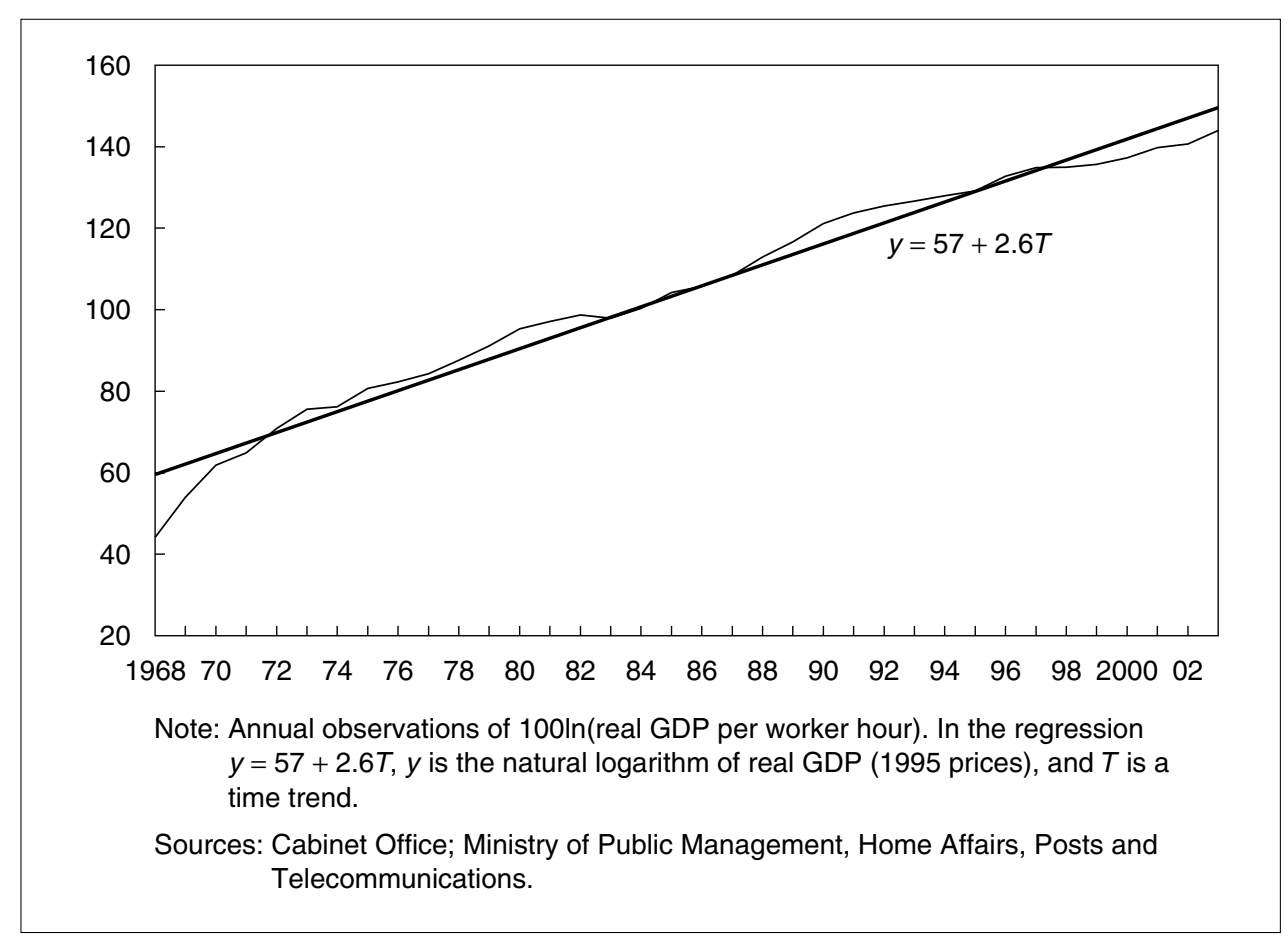

Figure 10 Growth of Real Wages and Productivity

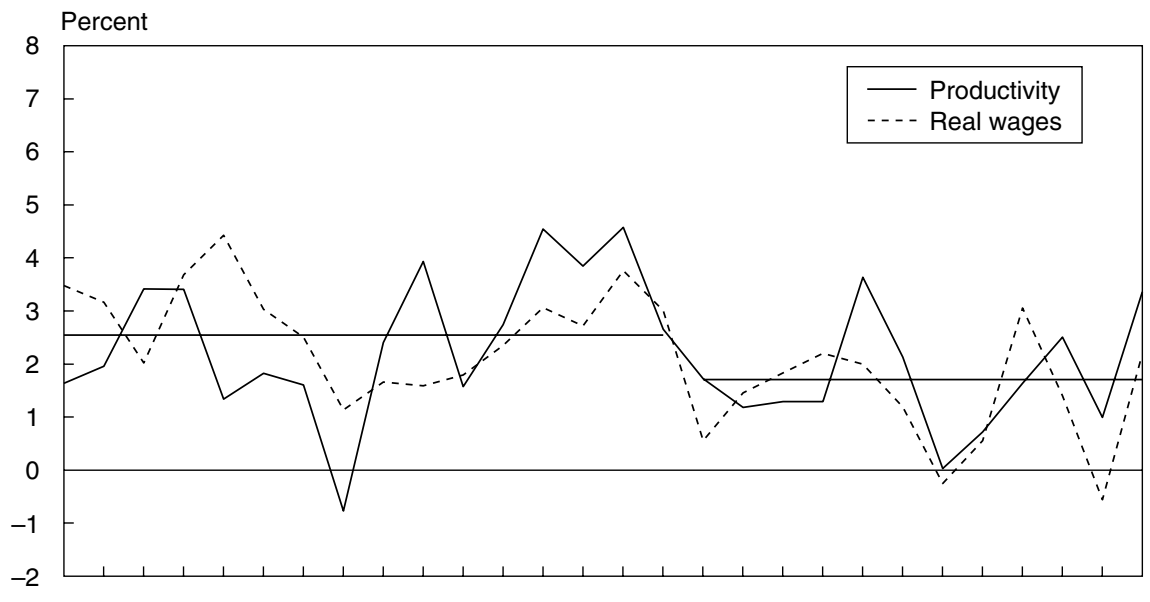

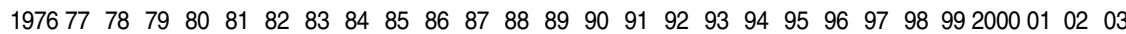

Note: Annual percentage changes in productivity and real wages. Productivity is calculated as real GDP/nonfarm hours worked. Real wages are calculated as compensation of employees/GDP deflator/number of employees. Productivity trend lines are for 1976-91 (2.5 percent) and 1992-2003 (1.7 percent).

Sources: Cabinet Office; Ministry of Public Management, Home Affairs, Posts and Telecommunications; Haver Analytics. 
rate has fallen about 2.5 percentage points. ${ }^{22}$ During this period, the ratio of private fixed nonresidential investment to GDP has remained steady at about 15 percent (the value that preceded the rise in the mid-1980s). Furthermore, since the beginning of 1998, employment of regular workers has fallen at about an annualized rate of 1 percent while employment of part-time workers has grown in excess of 3 percent. The substitution of part-time for full-time workers lowers the average wage rate, but may lower productivity by replacing experienced with inexperienced workers (Figure 11).

Given the current economic recovery, another question is the magnitude of the negative output gap. The answer to that question determines how long the Japanese economy can grow above its long-run potential. The Bank of Japan (2003a) estimated the output gap at -10 percent in $2002 /$ III. One way to measure the disappearance of the output gap is to observe how quickly the unemployment rate approaches its natural value. (The natural rate of unemployment is the value at which inflation begins to rise.)

A Phillips curve (a scatter plot of observations with CPI inflation on the vertical axis and the unemployment rate on the horizontal axis) for Japan is basically flat at unemployment rates above 3 percent. At unemployment rates below 3 percent, inflation begins to rise. Three percent then is an estimate of the natural rate of unemployment. However, structural changes in the Japanese labor market such as

Figure 11 Average Hourly Earnings and Ratio of Part-Time to Total Workers

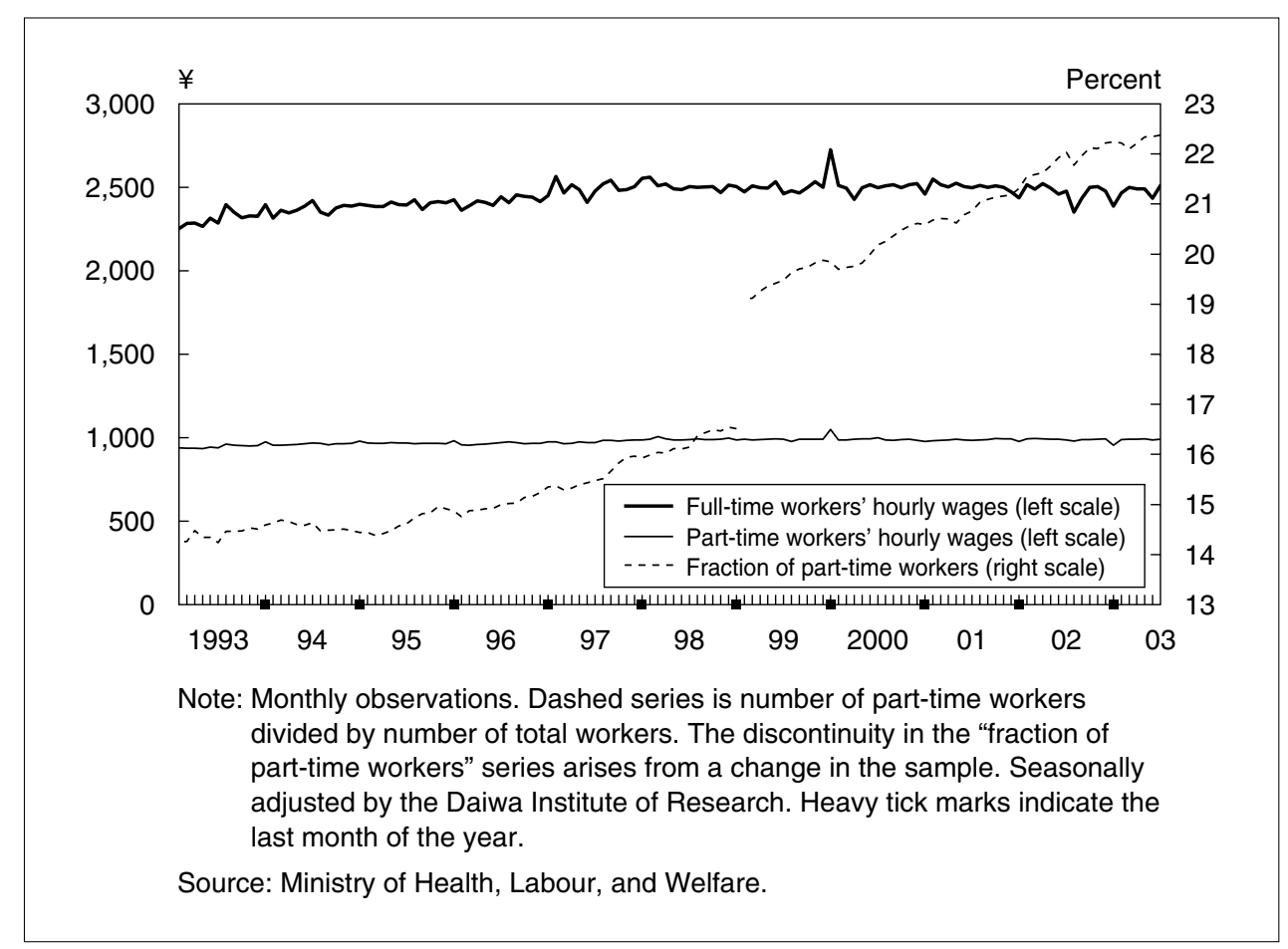

22. The figures are from the Ministry of Public Management, Home Affairs, Posts and Telecommunications and the Ministry of Health, Labour and Welfare. 
increased voluntary quit ratios and a skill mismatch suggested by a rise in the job offers-to-applicants ratio suggests that this number may be somewhat too low (Matsuoka [2004]).

\section{E. Issues of Political Economy}

The Bank of Japan Law is silent on whether the BOJ should maintain a positive value of its capital account. (It does provide for retained earnings to be paid into a reserves fund to offset capital losses.) For a central bank, maintenance of solvency is an institutional safeguard for protecting its independence. A central bank needs protection against political pressures to use its seigniorage revenues to buy the debt of insolvent firms and banks. ${ }^{23}$ For this reason, it is natural that the BOJ should avoid the precedent of becoming insolvent. It would be hesitant to put large amounts of assets susceptible to capital loss on its books because adverse price movements could make its capital account negative. In particular, if the BOJ buys long-term JGBs, a rise in interest rates associated with the end of deflation would create large capital losses.

Several options exist for dealing with this situation. Starting in 2004, the BOJ no longer marked to market its JGB holdings. A rise in market rates would then not affect the BOJ's balance sheet. Of course, the BOJ would have to realize losses if it sold JGBs. Such a situation could arise when short-term interest rates become positive and the call market revives. The current high level of CABs would then become excessive. In this situation, there is an alternative to selling JGBs. The BOJ could sell its own debt (bills drawn on the BOJ, as provided for in Article 33 of the Bank of Japan Law) and increase reserve requirements. The $\mathrm{BOJ}$ could also negotiate a response in advance with the Ministry of Finance (MOF). The BOJ and the MOF could agree publicly in advance that in the event of insolvency the BOJ would increase the percentage of retained earnings until the reserves fund reached its normal level.

\section{Concluding Comment}

The change in direction of U.S. monetary policy under Paul Volcker is instructive (Hetzel [1986]). In 1979, expectations of inflation became unmoored and outraced increases in the funds rate. Monetary policy did not provide a nominal anchor. Before 1979, the predominant view within the Federal Reserve was that inflation arose from a variety of non-monetary factors such as wage-push pressures and supply shocks raising the price of food and energy. The political system did not assign to the Fed responsibility for the control of inflation, and the the Fed did not seek that responsibility.

Volcker changed operating procedures to emphasize the Fed's control over money creation (Hetzel [1982]). He made the foundation of monetary policy the control of inflationary expectations. Credibility came only slowly. However, Volcker made clear that he would raise the funds rate to whatever level was necessary to establish 
Fed credibility. In 1981, the funds rate rose to 21 percent. No one knew whether financial markets could withstand the strain. In 1982, the U.S. economy entered into its worst postwar recession. Unemployment rose to 9 percent.

In 1983, inflation fell from 12 percent to 4 percent. The Volcker disinflation exercised a profound influence on the political and intellectual environment. Prior to this episode, the consensus held that maintenance of price stability required a socially unacceptable level of unemployment. When the Fed brought the inflation rate down and kept it down with only a moderate unemployment rate, the consensus changed. Governments became willing to assign responsibility for price stability to central banks and give them the independence necessary to achieve it.

Japan's situation is now similar in many ways to that of the United States in 1979. Japan has experienced deflation for a significant period. Changing expectations will be difficult. However, to lay a solid basis for monetary policy, the BOJ must change those expectations to conform to its objective of price stability. Volcker established credibility by making clear that the Fed would raise the funds rate to whatever level was necessary to restrain money growth and lower the public's expectation of inflation. The BOJ could make clear that it is ready to expand its portfolio of illiquid assets to increase the monetary base by whatever amount is necessary to revive money growth, restore the expectation of price stability, and maintain price stability. 


\section{References}

Bank of Japan, "Publications of the Monetary Policy Meeting on January 15 and 16, 2002," Bank of Japan Quarterly Bulletin, 10 (2), 2002a, p. 19.

—., "Money Market Operations in FY2001," Market Review, No. 2002-E-3, 2002b, p. 1.

_ - "The Output Gap and the Potential Growth Rate: Issues and Applications as an Indicator for the Pressure on Price Change, Bank of Japan Quarterly Bulletin, 11 (2), 2003a, pp. 203-244.

—_, "Money Market Operations in FY2002," Market Review, No. 2003-E-2, 2003b, p. 2.

Eggertsson, Gauti B., and Michael Woodford, "The Zero Bound on Interest Rates and Optimal Monetary Policy," Brookings Papers on Economic Activity, 1, 2003, pp. 139-211.

Hayashi, Fumio, and Edward C. Prescott, "The 1990s in Japan: A Lost Decade," Review of Economic Dynamics, 5, 2002, pp. 206-235.

Hetzel, Robert L., "The October 1979 Regime of Monetary Control and the Behavior of the Money Supply in 1980," Journal of Money, Credit and Banking, 14, May, 1982, pp. 234-251.

_ - "The Rules versus Discretion Debate over Monetary Policy in the 1920s," Economic Review, 71, Federal Reserve Bank of Richmond, November/December, 1985, pp. 3-14.

, "Monetary Policy in the Early 1980s," Economic Review, 72, Federal Reserve Bank of Richmond, March/April, 1986, pp. 20-32.

, “Japanese Monetary Policy: A Quantity Theory Perspective," Economic Quarterly, 85, Federal Reserve Bank of Richmond, Winter, 1999, pp. 1-25.

, "Japanese Monetary Policy and Deflation," Economic Quarterly, 89, Federal Reserve Bank of Richmond, Summer, 2003, pp. 21-52.

, "How Do Central Banks Control Inflation?" Economic Quarterly, 90, Federal Reserve Bank of Richmond, Summer, 2004.

Matsuoka, Mikihiro, “3Q 2003 GDP,” Economics, Deutsche Bank Group, November 14, 2003.

—_. "Price Indices and Capex Deflator," Economics, Deutsche Bank Group, February 16, 2004.

Meulendyke, Ann-Marie, U.S. Monetary Policy \& Financial Markets, Federal Reserve Bank of New York, 1998.

Saito, Makoto, and Shigenori Shiratsuka, "Financial Crises as the Failure of Arbitrage: Implications for Monetary Policy," Monetary and Economic Studies, 19 (S-1), Institute for Monetary and Economic Studies, Bank of Japan, 2001, pp. 239-270.

Sekine, Toshitaka, "Financial Liberalization, the Wealth Effect, and the Demand for Broad Money in Japan," Monetary and Economic Studies, 16 (1), Institute for Monetary and Economic Studies, Bank of Japan, 1998, pp. 35-56. 
24 MONETARY AND ECONOMIC STUDIES/OCTOBER 2004 